\title{
Technology Transfer Performance and Competitive Advantage: Evidence from Yemen
}

\author{
Mohammed Saleh Al-Abed ${ }^{1}$, Zainal Ariffin Ahmad ${ }^{1} \&$ Muhammad Anuar Adnan ${ }^{2}$ \\ ${ }^{1}$ College of Graduate Studies, Universiti Tenaga Nasional (UNITEN), Kajang, Malaysia \\ ${ }^{2}$ Department of Finance and Economics, College of Business Management and Accounting, Universiti Tenaga \\ Nasional (UNITEN), Bandar Muadzam Shah, Malaysia \\ Correspondence: Mohammed Saleh Al-Abed, College of Graduate Studies, Universiti Tenaga Nasional \\ (UNITEN), 4300 Kajang, Selengor, Malaysia. E-mail: alabbed@gmail.com
}

Received: October 28, 2013 Accepted: December 16, 2013 Online Published: January 27, 2014

doi:10.5539/ass.v10n3p195 URL: http://dx.doi.org/10.5539/ass.v10n3p195

\begin{abstract}
Most developing countries are relying more on technology transfer (TT) in different industries. Gaining the optimum benefits from implementing the TT process is the current issue in these countries. Based on the resource-based view (RBV) and knowledge-based view (KBV) perspectives, this paper aims to examine the relationship between technology transfer performance and competitive advantage. Using the quantitative research approach, the theoretical model and hypothesized relationships among the variables were tested based on empirical data collected from 514 managers and engineers selected randomly from nine oil and gas companies in Yemen. Structural equation modeling (SEM) was used for the purpose of analyzing the collected data. The study provides empirical evidence on the relationship between TT performance and competitive advantage, and it confirmed that TT performance is a strong predictor of competitive advantage. In addition, a set of practical implications is provided as well for the Government of Yemen, policy makers and managers especially those who are operating in the oil and gas industry in Yemen.
\end{abstract}

Keywords: technology transfer, technology transfer performance, competitive advantage, Yemen, oil and gas

\section{Introduction}

The reason behind encouraging the process of technology transfer (TT) by developing countries is due to the fact that TT can positively stimulate the economy (Schnepp, Von Glinow \& Bhambri, 1990). Waroonkun (2007) mentioned that recipient countries will achieve some advancement in their economies once they have the ability to absorb the transferred technology. The economic advancement is concerned with the degree to which TT projects have improved the competitiveness of local companies in the domestic and international market and with the degree to which TT projects has empowered the technology receiver to perform at a higher level (Di-Benedetto et al., 2003).

Despite the rich body of literature dealing with technology transfer performance, most of the previous studies evaluate TT performance from the financial view and according to the company performance. Authors such as Geringer and Herbert (1991), and Hansen and Wernerfelt (1989) evaluated TT performance according to the firm performance and economic components. While other studies measured TT performance based on the its activities (Schroer, Farrington, Messimer \& Thornton, 1995; Szulanski, 1996). Technology transfer performance is defined as the outcome attained for local companies from implementing technology transfer projects with foreign companies (Waroonkun, 2007).

On the other hand, when studying the resources of competitive advantage (CA), previous studies and researches mentioned that there are several drivers for competitive advantage used as resources. A question on how transferred knowledge and technology form a competitive advantage is implicitly posed by the resource-based view (RBV) and knowledge-based view (KBV) (Lin, 2003). Previous literature has observed that technologically driven and tacit knowledge are difficult to imitate, where firms possess imitable technology resources will enjoy sustainable competitive advantage (Bettis \& Hitt, 1995; Teece, 1977).

The main focus of the RBV and KBV perspectives is to show the ability of firms to develop and attain competitive advantage from imitable knowledge and resources (Barney, 1991). From the knowledge-based 
perspective, knowledge is more challenging to imitate and it is considered as an essential resource for firms (Mowery \& Rosenberg, 1989). Consequently, the knowledge acquisition is conceived as strategic assets, in which is considered a source of competitive advantage (Nonaka, 1994).

One of the keys to success in an organization has been identified in terms of taking advantage of and applying knowledge acquired from TT to strengthen firm's capability (Gilbert \& Cordey-Hayes, 1996). Consequently, firms that acquire and utilize technology effectively are able to compete in domestic and international market (Lynn, Skov, \& Abel, 1999). The Gilbert and Cordey-Hayes (1996) model stated that the ability to gain and apply developmental technology can improve the mean performance level which in turn will maximize the competitive advantage of the firm.

Sazali, Haslinda and Raduan(2009) mentioned that technology transfer could make a significant contribution to competitive advantage. Liao and $\mathrm{Hu}$ (2007) reported that transferred technology benefitted the Taiwan's semiconductor industry by enhancing the organizations' competitive advantage. Based on the RBV and KBV perspectives, technology transfer can improve knowledge, local working practices and technology adoption capability, which in turn contribute to the competitive advantage (Barney, 1991; Cohen \& Levinthal, 1990; Lin, 2003). However, there have been inadequate empirical studies on the relationship between technology transfer performance and competitive advantage. Thus, this study fills the gap in the literature by empirically examining the relationship between technology transfer performance and competitive advantage.

\section{Theory and Hypothesis}

Technology transfer performance forms a wide interest among researchers seeking a deep understanding of the technology transfer process across boundaries. Several studies applied objectives and subjective measurements for the purpose of evaluating technology transfer performance. Essentially, organizational performance was viewed in terms of compiled competencies obtained by organizations or via exceeding or meeting the financial means (Kogut \& Zander, 1992; Prahalad \& Hamel, 1990). Relying on the initial projection, economic segments, business performance, joint venture period, success and overall achievement with performance are the diverse measures used by researchers (Geringer \& Herbert, 1991; Hansen \& Wernerfelt, 1989) for the purpose of determining the performance of firms.

On the other hand, measuring TT performance based on the stages of TT was studied by Bradley, McErlean, and Kirke (1995); Narayanan and Lai (1993); and Santikarn (1981). Santikarn (1981) listed four major concepts. The first step is when the technology is used. Here, once the transferred technology is used from the recipient company, it is remarked as transferred, of which associated with transportation of the technology. For the second concept, once the local workforce is able to comprehend the technology, it is perceived as transferred. Thus, a transfer has been accomplished only after the workers are skillful in utilizing the transferred technology. While the third concept indicates that technology is transferred once it disperses among different sections in the receiver company via dynamic distribution actions. Finally, the fourth concept indicates that when the employees are capable to adapt the transferred technology to accommodate the requirements of their business environment, technology transfer occurs. However, the overlap with the mentioned concepts may occur, besides they are not mutually exclusive (Santikarn, 1981).

In addition, some other measurements are used in order to measure TT performance such as the activities measurement and the results measurement (Schroer et al., 1995). The interaction and communication between the providing firms and receiving firms are pertained to the measurement of activities, whereas the results measurement related to the benefits and advantages which comprise the reduction of costs, the quality improvements and the creation of jobs (Schroer et al., 1995).

Steele (1988) identified the process of technology implementation and strengthening the operations in the company, for the purpose of measuring technology transfer performance. His study revealed that the effectiveness of TT performance is strongly affected by technology absorptive capacity. In another study done by Chinho, Bertram, and Shofang (2002) in the context of Taiwan's electronic industry, TT measurement was quite dissimilar from the prior studies. Their measurement was based on the profit and factors of implementation and enhancing the technical operations in order to operationalize the performance of TT.

The transfer of technology to the host companies is considered as the initial outcome of TT projects (Gold, Malhotra, \& Segars, 2001). Consequently, when transferred technology is accepted, it will lead to improved working practices in the immediate term and ideally become the standard over the long-term. The outcome of TT is used to measure the performance of TT, as it is concerned with the knowledge improvement, the TT improvement of the local working practices and the effect of TT projects for improving the technology adoption capability of the local companies over the longer term (Gilbert \& Cordey-Hayes, 1996; Gold et al., 2001). 
Based on the study of Gilbert and Cordey-Hayes (1996), Waroonkun (2007) measured the performance of technology transfer via the outcome attained from the process of TT, of which he described it to be an added value for this process. In his study, Waroonkun (2007) proved that TT performance can be evaluated through measuring the improved knowledge, the improvements in working practices and the improvement on technology adoption (Gilbert \& Cordey-Hayes, 1996; Gold et al., 2001).

Pinzon (2007) concluded that an improved technological situation in developing countries could lead to a stronger economy, democracy, social development and poverty reduction. Takim, Omar, and Nawawi (2008) reckoned that technology transfer from developed to developing countries influences the local firms' performance and competitive advantage. Benefits are recognized in the form of enhancing project efficiency, maximizing profits strategic goal, personal development, specialized learning, minimizing production cost and increasing production quality (Rogers, 1995). Sazali et al. (2009) found that the relationship between technology transfer characteristics and the degree of technology transfer significantly affect local firms' performance. In addition, Gilbert and Cordey-Hayes (1996) mentioned that the ability to acquire and utilize developmental technology can increase the mean performance level which in turn will maximize the competitive advantage of the firm. Therefore, this study hypothesizes the following:

H1: There is a significant relationship between TT performance and competitive advantage.

\section{Methods}

\subsection{Data and Sample}

The population in this study includes managers and engineers working with the Yemeni oil and gas companies. The total number of Yemeni oil and gas companies involved in TT projects with foreign companies was 9 companies with a total number of 14,138 employees and the total number of employees working at the managerial level and engineers was 4,532 (Ministry of Oil and Minerals, 2010). A sample size $(n=600)$ was randomly selected from the managers and engineers strata to obtain a sample large enough to achieve the statistical significance and a good model fit in structural equation modelling (SEM) (Kline, 2011). A self administered questionnaire was used for the purpose of data collection. The respondents were given two weeks to respond. The respond rate was $86 \%$ of the sample size and a total of 514 questionnaires were used.

\subsection{Instrument and Measures}

In this study, the questionnaire was used as the research instrument. Since this study focused on Yemeni oil and gas companies and it was conducted in Yemen, the questionnaire was written in English and was translated in Arabic language using back-to-back translation method proposed by Brislin (1980). For all the questions devised, a 5 point Likert scales were used. Cooper, Schindler and Sun (2006) stated that a Likert scale is a summated rating scale made up of phrases that exhibit either a positive or undesirable attitude toward the object of interest (Cooper, Schindler, \& Sun, 2006). The options given in the questionnaires are listed as; strongly disagree, disagree, neutral, agree and strongly agree. Cooper et al. (2006) mentioned that increasing the number of scale will lead to increase the reliability of the measure accordingly.

\subsubsection{Dependent Variable - Competitive Advantage}

In this study, cost and quality were identified as two dimensions under competitive advantage (Li et al., 2006; Roth \& Miller, 1990; Wheelwright, 1978). Cost as one dimension of competitive advantage has been described by Li et al. (2006) as the ability of an organization to compete against major competitors based on low cost. While the quality is the ability of an organization to offer product quality and performance that creates higher value for customers (Koufteros, 1995). These dimensions are representing the competitive advantage variable and this study adapted eight questions from Al-Zoubi (2012), Feng, Sun, and Zhang (2010) and Tan (2009) to measure this variable as shown in Table 1. The value of Cronbach's Alpha for competitive advantage was high (.88). 
Table 1. Measuring competitive advantage

Competitive Advantage

The company implements a low cost strategy.

The company is able to compete based on low cost.

The company has an effective control of labor and material.

The company conducts programs for resource saving.

The company is committed to quality production.

High standards are applied for all technical operations

The company focuses on the improvement of existing processes and operations.

The company works hard to enhance the technological capabilities to meet the competitive necessities.

Adapted from Al-Zoubi (2012), Feng et al. (2010), and Tan (2009)

\subsubsection{Independent Variable - TT Performance}

This study adapts a multi-dimensional approach in measuring this variable (Gilbert \& Cordey-Hayes, 1996; Gold et al., 2001; Pavlou, 2004; Waroonkun 2007). Based on the RBV and KBV perspectives, this study operationalizes technology transfer performance as the outcome gained from the process of technology transfer in terms of three dimensions: (1) Improved knowledge in terms of management techniques, oil and gas technology, business management, TT implementation, (2) Improved working practices in terms of resources allocation, knowledge integration, transformation and applications, and (3) Long-term adoption of transferred technology in terms of adopting new approaches in project management, oil and gas methods, advanced technologies, and new skills. Twelve questions were adapted from Pavlou (2004) and Waroonkun (2007) to measure TT performance as shown in Table 2. The value of Cronbach Alpha for TT performance was high (.92).

Table 2. Measuring technology transfer performance

Technology Transfer Performance

Knowledge on project management techniques and tools is improved.

Knowledge on oil and gas technology is improved.

Knowledge on oil and gas business management is improved.

Knowledge on implementing TT is improved.

The company ensures an appropriate allocation of resources.

The company can successfully integrate the exiting knowledge with new information and knowledge acquired.

The company is more effective in transforming existing information into new knowledge.

The company can successfully exploit internal and external knowledge into concrete applications.

The company adopts new approaches in project management.

The company adopts more advanced technologies.

The company adopts new approaches in oil and gas methods.

The company adopts new transferred skills.

Adapted from Pavlou (2004); Waroonkun (2007)

\section{Results}

\subsection{Descriptive Statistics}

From the descriptive statistics shown in Table 3, the mean of competitive advantage was 3.97, which indicates that on average the respondents agree on the competitive advantage characteristics. Both cost and quality had a minimum value of 1 (strongly disagree) with a maximum value of 5 (strongly agree) respectively. The mean of technology transfer performance was 4.06, which indicates that the respondents agree on the performance of the technology transfer. For the improved knowledge, the highest scale respondent chose was strongly agree (5) with 
a mean of 4.13. For improved working practices, the highest score was 5 representing strongly agree and the mean was 4.0 while the mean of long-term adoption was 4.05 . This shows that the effectiveness of technology transfer was high.

Table 3. Descriptive statistics

\begin{tabular}{lcccc}
\hline & Variable & $\mathrm{N}$ & Mean & SD \\
\hline TT Performance & $\mathbf{5 1 4}$ & $\mathbf{4 . 0 6}$ & $\mathbf{. 6 0}$ & .65 \\
Improved Knowledge & 514 & 4.13 & .72 & .70 \\
Improved Working Practices & 514 & 4.00 & $\mathbf{. 6 4}$ & .74 \\
Long-term Adoption & 514 & 4.05 & $\mathbf{3 . 9 7}$ & $\mathbf{7 3}$ \\
Competitive Advantage & $\mathbf{5 1 4}$ & 5.04 & 3.91 & \\
Cost & 514 & 514 & &
\end{tabular}

\subsection{Final Structural Model}

By utilizing SEM (structural equation modeling), Figure 1 shows all the path analyses and the variance explained $\left(\mathrm{R}^{2}\right)$ for the endogenous variable (competitive advantage-CA). As illustrated in Figure 1 and Table 4, the result from the final structural model shows that TT performance (exogenous variable) in this research explain $62 \%$ of the variation in competitive advantage (endogenous variable). In addition, the level of model fit was good and satisfied. Chi-Square was 288.188 and df (degree of freedom) was 161 . The relative Chi-Square $(\chi 2 / \mathrm{df})$ was 1.79 , below the 5.0 required for good fit (Hair, Anderson, Tatham \& Black, 2006). The p-value related with the results was significant at $p<.001$. Hair et al. (2006) mentioned that $\mathrm{p}$-value is sensitive to the sample size and it may occur significant if using large sample size. In absolute fit indices, the goodness of fit index (GFI) was .95, well higher than .90 (Hair, Black, Babin, Anderson \& Tatham, 2010). Comparative fit index (CFI) was .98, above the .90 required for good fit (Hu \& Bentler, 1999). Root mean square error of approximation (RMSEA) was .04, below the 0.08 required for good fit (Byrne, 1998). For the final structural model, the results indicated a very good fit model.

Table 4. Goodness-of-fit statistics for final structural model

\begin{tabular}{|c|c|c|c|}
\hline $\begin{array}{c}\text { Goodness-of-fit } \\
\text { Statistics }\end{array}$ & & Level of Acceptance & Index Value \\
\hline \multicolumn{4}{|l|}{ Absolute Fit Measures } \\
\hline Chi-square & $\mathrm{X}^{2}$ & $p>0.05$ & $\begin{array}{c}288.188 \\
(p=0.000)\end{array}$ \\
\hline Degree of freedom & Df & $\geq 0$ & 161 \\
\hline Root mean square error of approximation & RMSEA & $<0.08$ & 0.04 \\
\hline Goodness of fit index & GFI & $>0.90$ & 0.95 \\
\hline \multicolumn{4}{|l|}{ Incremental Fit Measures } \\
\hline Comparative fit index & CFI & $>0.90$ & 0.98 \\
\hline \multicolumn{4}{|l|}{ Parsimonious Fit Measures } \\
\hline Relative Chi-Square & $\mathrm{X}^{2} / \mathrm{df}$ & $<5$ & 1.79 \\
\hline
\end{tabular}

The parameter estimates for all constructs are presented in Table 5. All standardized regression weights exceeded the recommended value of .50 , indicating that all values are significant, and therefore convergent validity for final structural model with all constructs was achieved and there is no cross-loading (Hair et al., 2006). 


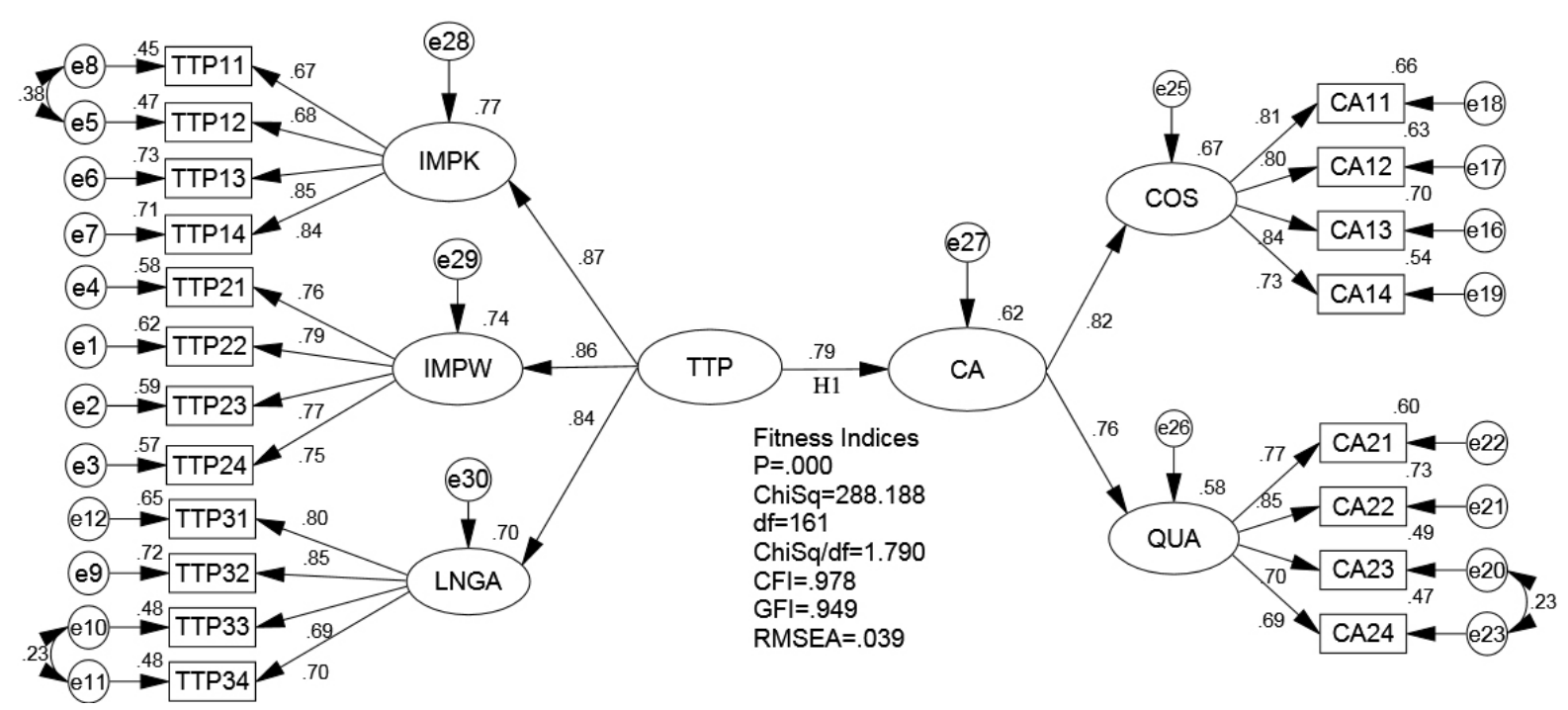

Figure 1. Final structural model

Table 5. Standardized regression weight

\begin{tabular}{lllc}
\hline & & & Estimate \\
\hline Cost & $\leftarrow$ & Competitive Advantage & .82 \\
Quality & $\leftarrow$ & Competitive Advantage & .76 \\
Improved Knowledge & $\leftarrow$ & TT Performance & .87 \\
Improved Working & $\leftarrow$ & TT Performance & .86 \\
Long-Term Adoption & $\leftarrow$ & TT Performance & .84 \\
\hline
\end{tabular}

\subsection{Hypothesis Testing}

For the purpose of testing the research hypothesis, standardized regression weight is used since it allows evaluating directly the effect of each exogenous variable on the endogenous variable (Hair et al., 2006).

H1: There is a significant relationship between TT performance and competitive advantage.

This hypothesis suggests that TT performance as an exogenous variable provides a significant contribution to competitive advantage as an endogenous variable. The results of SEM showed that the standardized regression weight of the structural path between TT performance and competitive advantage was positive and significant, in which path coefficient $=.79$, C.R. $=11.90$ and $p=.00$ (Table 6 ). Therefore, the research hypothesis H1 is supported by the data. This may suggest that the higher the level of TT performance, the greater the extent of competitive advantage for Yemen oil and gas companies.

Table 6. Standardized regression weights of structural model

\begin{tabular}{ccccccccc}
\hline Hypothesis & \multicolumn{2}{c}{ Standardized Regression Weights } & Estimate & S.E. & C.R. & $\boldsymbol{p}$ & Result \\
\hline $\mathrm{H} 1$ & Competitive Advantage & $\leftarrow$ & TT Performance & .79 & .07 & 11.90 & $* * *$ & Supported \\
\hline Note: $* * * \mathrm{p} \leq .001$ & & & & & & &
\end{tabular}

\section{Discussion and Conclusion}

TT performance identified by improved knowledge, improved working practices, and long-term adoption of transferred technology were found to have significant impact on competitive advantage in Yemeni oil and gas companies. The findings are consistent with Takim et al. (2008) who reckoned that technology transfer from developed to developing countries influences the local firms' performance and competitive advantage. As noted 
by Rogers (1995), some benefits from technology transfer include minimizing production cost and increasing product quality. Therefore, this study lends support to the fact that improved knowledge, improved working practices, and long-term adoption of transferred technology occurred to be most important predictors of competitive advantage in oil and gas industry.

The findings of this study show that with improvements in knowledge acquired from foreign companies, working practices, and long-term adoption of transferred technology, there is more inducement to establish competitive advantage by producing with low cost and high quality, especially in oil and gas industry. Gilbert and Cordey-Hayes (1996), Nakamura and Nakamura (2004) and Sazali et al. (2009) found that technology transfer from the foreigners have a positive impact on firm's performance. From the RBV, knowledge as a major source can lead to develop competitive advantage (Barney, 1991).

In addition, the findings of this study are consistent with Gilbert and Cordey-Hayes (1996) who stated that the ability of local companies to acquire and utilize new technology can increase their performance which in turn will maximize their competitive advantage, and consistent with Lynn et al. (1999) who concluded that companies gain advanced technology and adopt it effectively are able to compete in domestic and international market.

This study contributed to the body of knowledge from the theoretical point of view. First, most of the previous studies evaluate TT performance from the financial view and according to the company performance (Geringer \& Herbert, 1991; Hansen \& Wernerfelt, 1989; Sazali et al., 2009; Schroer et al., 1995; Szulanski, 1996; Takim et al., 2008). However, with regards to technology transfer, this study measured its performance according to the improved knowledge, improved working practices and long-term adoption of transferred technology in order to investigate their impact on competitive advantage. Consequently and based on RBV and KBV perspectives, the empirical findings of this study confirmed that TT performance can be evaluated by measuring the level of improved knowledge, improved working practices and long-term adoption of transferred technology.

Second, this study conducted a questionnaire survey to test the theoretical link between TT performance and CA. The empirical findings confirmed that TT performance is a strong predictor of competitive advantage. In addition, TT performance had a significant influence on competitive advantage. It is the critical role of TT process and its outcome as major sources of a firm's competitive advantage that makes the key contribution of the research model.

The results of this study provide empirical evidence that technology transfer contributes to the competitive advantage. Therefore TT is considered as a main source of CA in Yemen oil and gas industry. By employing the outcomes of TT, which are centered on the knowledge improvements, working practices improvements, and long-term technology adoption, Yemen oil and gas companies can improve the production quality and reduce the exploration and production cost. Thus, it is important for both the Government of Yemen and the oil and gas companies to understand that competitive advantage can be achieved through the success of the technology transfer process resulting from government and organization support and the right choice of technology and transferor companies as well as technology transfer mechanisms.

For future work, it would be beneficial to include the organization structure and size as moderator variables, in order to measure its effect in the relationship between TT performance and CA. These two variables may play a critical role by maximizing or minimizing the relationship between TT performance and CA. Thus, it is recommended for future studies to include their effects.

\section{References}

Al-Zoubi, M. R. (2012). Leadership competencies and competitive advantage empirical study on Jordan telecommunications. European Journal of Business and Management, 4(7). Retrieved from http://www.iiste.org/Journals/index.php/EJBM/article/viewFile/1832/1785

Barney, J. (1991). Firm resources and sustained competitive advantage. Journal of Management, 17(1), 99-120. Retrieved from http://business.illinois.edu/josephm/BA545_Fall\%202013/Barney\%20(1991).pdf

Bettis, R. A., \& Hitt, M. A. (1995). The new competitive landscape. Strategic Management Journal, 16(S1), 7-19. Retrieved from http://onlinelibrary.wiley.com/doi/10.1002/smj.4250160915/pdf

Bradley, A., McErlean, S., \& Kirke, A. (1995). Technology transfer in the Northern Ireland food processing sector. British Food Journal, 97(10), 32-35. Retrieved from http://www.emeraldinsight.com/journals.htm?articleid=870316

Brislin, R. W. (1980). Translation and content analysis of oral and written materials. In H. C. Triandis, \& J. W. Berry (Eds.), Handbook of cross-cultural psychology (pp. 389-444). Boston, MA: Allyn and Bacon. 
Retrieved

from http://books.google.com.my/books/about/Handbook_of_cross_cultural_psychology.html?id=a87tAAAAM AAJ\&redir_esc $=y$

Byrne, B. M. (1998). Structural equation modeling with LISREL, PRELIS, and SIMPLIS: Basic concepts, applications, and programming. New Jersey: Lawrence Erlbaum Associates.

Chinho, L., Bertram, T., \& Shofang, C. (2002). The critical factors for absorptive capacity. Industrial Management \& Data System, 102(6), 300-308. Retrieved from http://www.emeraldinsight.com/journals.htm?articleid=1454054\&show=pdf

Cohen, W. M., \& Levinthal, D. A. (1990). Absorptive capacity: A new perspective on learning and innovation. Administrative Science Quarterly, 128-152. $\quad$ Retrieved from https://faculty.fuqua.duke.edu/ charlesw/s591/Bocconi-Duke/Papers/C10/CohenLevinthalASQ.pdf

Cooper, D. R., Schindler, P. S., \& Sun, J. (2006). Business research methods. New York, NY: McGraw-Hill Irwin. Retrieved from http://books.google.com.my/books/about/Business_Research_Methods.html?id=_4zWAAAAMAAJ

Dhanaraj, C., Lyles, M. A., Steensma, H. K., \& Tihanyi, L. (2004). Managing tacit and explicit knowledge transfer in IJVs: The role of relational embeddedness and the impact on performance. Journal of International Business Studies, 35(5), 428-442. Retrieved from http://www.palgrave-journals.com/jibs/journal/v35/n5/abs/8400098a.html

Di-Benedetto, C. A., Calantone, R. J., \& Zhang, C. (2003). International technology transfer: Model and exploratory study in the People's Republic of China. International Marketing Review, 20(4), 446-462. Retrieved from http://www.emeraldinsight.com/journals.htm?articleid=855545

Feng, T., Sun, L., \& Zhang, Y. (2010). The effects of customer and supplier involvement on competitive advantage: An empirical study in China. Industrial Marketing Management, 39, 1384-1394. Retrieved from http://www.sciencedirect.com/science/article/pii/S0019850110000568

Geringer, J. M., \& Herbert, L. (1991). Measuring performance of international joint ventures. Journal of International Business Studies, 22(2), 249-263. Retrieved from http://ideas.repec.org/a/pal/jintbs/v22y1991i2p249-263.html

Gilbert, M., \& Cordey-Hayes, M. (1996). Understanding the process of knowledge transfer to achieve successful technological innovation. Technovation, 16(6), 301-312. Retrieved from http://www.sciencedirect.com/science/article/pii/0166497296000120

Gold, A. H., Malhotra, A., \& Segars, A. H. (2001). Knowledge management: an organizational capabilities perspective. Journal of Management Information Systems, 18(1), 185-214. Retrieved from http://public.kenan-flagler.unc.edu/faculty/malhotra/kmjmis.pdf

Hair, J. F., Anderson, R. E., Tatham, R. L., \& Black, W. C. (2006). Multivariate data analysis (6th ed.). New Jersey: Pearson Prentice Hall. from http://www.gobookee.org/hair-et-al-2006-multivariate-data-analysis/

Hair, J. F., Black, W., Babin, B. Y. A., Anderson, R., \& Tatham, R. (2010). Multivariate data analysis (7th ed.). New Jersey: Pearson Prentice Hall. Retrieved from http://www.pearsonhighered.com/educator/product/Multivariate-Data-Analysis/9780138132637.page

Hansen, G. S., \& Wernerfelt, B. (1989). Determinants of firm performance: The relative importance of economic and organizational factors. Strategic Management Journal, 10(5), 399-411. Retrieved from http://web.mit.edu/bwerner/www/papers/DeterminantsofFirmPerformance-TheRelativeImportanceofEcono micandOrganizationalFactors.pdf

Hu, L., \& Bentler, P. M. (1999). Cutoff criteria for fit indexes in covariance structure analysis: Conventional criteria versus new alternatives. Structural Equation Modeling, 6(1), 1-55. Retrieved from http://www.tandfonline.com/doi/abs/10.1080/10705519909540118\#.Um7c-_1HIrI

Kline, R. B. (2010). Principles and practice of structural equation modeling (3rd ed.). NY: Guilford Press. Retrieved from http://www.guilford.com/cgi-bin/cartscript.cgi?page=pr/kline.htm

Kogut, B., \& Zander, U. (1992). Knowledge of the firm, combinative capabilities, and the replication of technology. Organization Science, 3(3), 383-397. Retrieved from http://www0.gsb.columbia.edu/faculty/bkogut/files/1992_OrgSci_Kogut_Zander.pdf 
Kogut, B., \& Zander, U. (1993). Knowledge of the firm and the evolutionary theory of the multinational corporation. Journal of International Business Studies, 625-645. Retrieved from http://aib.msu.edu/awards/24_4_93_625.pdf

Koufteros, X. (1995). Time-based manufacturing: Developing a nomological network of constructs and instrument development (Doctoral dissertation). University of Toledo, Toledo, OH. Retrieved from http://www.utoledo.edu/business/phd/PHDDocs/Koufteros_-_Time_based_competi.pdf

Liao, S. H., \& Hu, T. C. (2007). Knowledge transfer and competitive advantage on environmental uncertainty: An empirical study of the Taiwan's industry. Technovation, 27, 402-411. Retrieved from http://www.sciencedirect.com/science/article/pii/S0166497207000223

Lin, B. W. (2003). Technology transfer as technological learning: A source of competitive advantage for firms with limited R\&D resources. $R \& D$ Management, 33(3), 327-341. Retrieved from http://onlinelibrary.wiley.com/doi/10.1111/1467-9310.00301/abstract

Lynn, G. S., Skov, R. B., \& Abel, K. D. (1999). Practices that support team learning and their impact on speed to market and new product success. The Journal of Product Innovation Management, 16(5), 439-454. Retrieved from http://onlinelibrary.wiley.com/doi/10.1111/1540-5885.1650439/abstract

Ministry of Oil and Minerals. (2010). Oil, gas and minerals statistics 2010. Yemen: Statistics Technical Committee, Ministry of Oil and Minerals.

Mowery, D. C., \& Rosenberg, N. (1989). Technology and the pursuit of economic growth. NY: Cambridge University Press. Retrieved from http://ideas.repec.org/a/eee/jeborg/v18y1992i1p137-141.html

Narayanan, S., \& Lai, Y. (1993). Human resource constraints on technology transfer: An empirical analysis of the electronics and electrical sector in Penang, Malaysia. The Singapore Economic Review, 38(2), 155-165.

Nonaka, I. (1994). A dynamic theory of organizational knowledge creation. Organization Science, 5(1), 14-37. Retrieved from http://citeseerx.ist.psu.edu/viewdoc/download?doi=10.1.1.115.2590\&rep=rep1\&type=pdf

Pavlou, P. A. (2004). IT-enabled dynamic capabilities in new product development: building a competitive advantage in turbulent environments. Los Angeles: University of Southern California. Retrieved from http://books.google.com.my/books/about/IT_enabled_Dynamic_Capabilities_in_New_P.html?id=v-kTOAA ACAAJ\&redir_esc $=\mathrm{y}$

Pinzon, P. (2007). The relationship between technology transfer and sustainable growth in developing countries. Paper presented at the 16th International Conference on Management of Technology, Miami Beach, Florida.

Prahalad, C., \& Hamel, G. (1990). The core competence of the corporation. Harvard Business Review, 68(3), 79-91. Retrieved

from https://faculty.fuqua.duke.edu/ charlesw/s591/willstuff/oldstuff/PhD_2007-2008/Papers/C08/Prahalad_Ha mel_1990.pdf

Rogers, E. M. (1995). Diffusion of innovations. New York: Free Press. Retrieved from http://www.d.umn.edu/ /rochfor/ireland/dif-of-in-ch06.pdf

Roth, A. V., \& Miller, J. G. (1990). Manufacturing strategy, manufacturing strength, managerial success, and economic outcomes. In J. Ettlie, M. C. Burstein, \& A. Fiegenbaum (Eds.), Manufacturing strategies (pp. 97-108). Boston, MA: Kluwer Academic Publishers.

Santikarn, M. (1981). Technology transfer: A case study. Singapore: Singapore University Press. Retrieved from http://www.jstor.org/discover/10.2307/25797714?uid=3738672\&uid=2\&uid=4\&sid=21102832392381

Sazali, W. A., Haslinda, A., \& Raduan, C. R. (2009). A holistic model of the inter-firm technology transfer based on integrated perspective of knowledge-based view and organizational learning. The Journal of International Social Research, 2(9), 408-422. Retrieved from http://umkeprints.umk.edu.my/465/

Schnepp, O., Von Glinow, M. A., \& Bhambri, A. (1990). United States-China technology transfer. Englewood Cliffs, NJ: Prentice Hall. Retrieved from http://trove.nla.gov.au/work/17602164?q\&versionId=20644709

Schroer, B. J., Farrington, P. A., Messimer, S. L., \& Thornton, J. R. (1995). Measuring technology transfer performance: A case study. The Journal of Technology Transfer, 20(2), 39-47. Retrieved from http://link.springer.com/article/10.1007/BF02280406

Steele, L. W. (1988). Evaluating the technical operation. Research Technology Management, 31(5), 11-18.

Szulanski, G. (1996). Exploring internal stickiness: Impediments to the transfer of best practice within the firm. 
Strategic Management Journal, 17, 27-43. $\quad$ Retrieved from http://gul.gu.se/public/pp/public_courses/course40530/published/1291620354679/resourceId/15964758/con tent/Szulanski1996\%20-\%20Theme\%203.pdf

Takim, R., Omar, R., \& Nawawi, A. H. (2008). International technology transfer (ITT) projects and development of technological capabilities in Malaysian construction industry: A conceptual framework. Asian Social $\begin{array}{llll}\text { Science, } & 4(8), & \text { Retrieved } & \text { from }\end{array}$ http://www.ccsenet.org/journal/index.php/ass/article/download/1170/1101

Tan, Y. (2009). Contractor's competitiveness and competitive strategy in Hong Kong (Unpublished doctral Thesis). The Hong Kong Polytechnic University, Hong Kong.

Teece, D. J. (1977). Time-cost tradeoffs: Elasticity estimates and determinants for international technology transfer projects. Management Science, 23(8), 830-837. Retrieved from http://pubsonline.informs.org/doi/abs/10.1287/mnsc.23.8.830

Waroonkun, T. (2007). Modelling international technology transfer in Thai construction projects (Unpublished doctoral Thesis). Griffith University, Australia.

Wheelwright, S. C. (1978). Reflecting corporate strategy in manufacturing decisions. Business Horizons, 21(1), 57-66. Retrieved from http://www.som.cranfield.ac.uk/som/dinamic-content/media/research/scrip/Reflectingcorporatestrategyinma nufacturingdecisions.pdf

\section{Copyrights}

Copyright for this article is retained by the author(s), with first publication rights granted to the journal.

This is an open-access article distributed under the terms and conditions of the Creative Commons Attribution license (http://creativecommons.org/licenses/by/3.0/). 